\title{
Gender Diversity of Audit Committees and Audit Fees: Evidence from Chinese Listed Companies
}

\author{
Rui Xiang \\ Department of Corporate Finance \& Accounting \\ Business School, Sichuan University \\ Chengdu, Sichuan, P. R. China 610064 \\ E-mail: xiangrui@scu.edu.cn \\ Meng Qin \\ Department of Corporate Finance \& Accounting \\ Business School, Sichuan University \\ Chengdu, Sichuan, P. R. China 610064 \\ E-mail: mengqin@stu.scu.edu.cn
}

Craig A Peterson (corresponding author)

Department of Finance \& Commercial Law

Haworth College of Business, Western Michigan University

Kalamazoo, MI 49509

E-mail: Craig.peterson@wmich.edu

Received: Nov. 9, 2015 Accepted: Dec. 14, 2015 Published: December 14, 2015

doi:10.5296/ajfa.v7i2.8550 URL: http://dx.doi.org/10.5296/ajfa.v7i2.8550

\begin{abstract}
This paper investigates whether women, who serve on the audit committee of the board, can have a significant impact in reducing audit fees paid by China's A-share listed companies during the period 2004 to 2007 . We show that audit committees composed of both men and


women pay significantly smaller audit fees. The relationship is significantly greater in non-state enterprises than that exhibited by state-owned enterprises and significantly greater in companies deemed to have weak management vis-à-vis strong management. Further analysis shows that the composition of the committee is irrelevant when management is strong, regardless of whether it provides guidance for a state-owned enterprise or a strictly public company. When management is deemed weak, however, gender diversity is associated with smaller fees.

Keywords: Corporate Governance, China, Audit Committees, Audit Fees, Gender Diversity 


\section{Introduction}

The People's Republic of China was governed as a planned economy until the 1990s when the government allowed companies to go public with multiple classes of stock. Joint-equity enterprises appeared in the 1980s, and in 1990 and 1991 stock exchanges were founded in Shanghai and Shenzhen, marking the beginning of China's equity market. The capital market has grown since then but corporate governance and market supervision lag developed countries (Allen, Qian \& Qian, 2005). Most listed companies are state-owned and management has generally retained its official administrative posts or ranks. Agency conflicts are common as corporate governance is still in its infancy. Management engages in rent-seeking activities and demands personal perquisites (Lin \& Lu, 2009). Firms lack effective market supervision and investors need protection.

That is not to say that the developed world's equity markets do not struggle with similar agency problems. For instance, the Sarbanes-Oxley Act (Pub.L. 107-204, 116 Stat. 745) was enacted July 30, 2002, "To protect investors by improving the accuracy and reliability of corporate disclosures made pursuant to the securities laws, and for other purposes." Title III Corporate Responsibility, $\$ 301$ Public Company Audit Committees sets forth standards including (3) independence of audit committee members. $\$ 407$ mandates audit companies include at least one member who is a financial expert. Similarly, the Securities Regulatory Commission and the National Economics and Trade Commission of the People's Republic of China jointly issued the Code of Corporate Governance for Chinese Listed Companies in 2002. Chapter III Directors and Board of Directors, $\S 6$ Special Committees of the Board states(52)in listed companies, the board of directors can form audit committees based on the decision of general meetings, most of the audit committee's members should be independent directors, and at least one member should have accounting expertise. It also lists clearly (54)the major responsibilities of audit committees. However, audit committee formation in China is voluntary, differing from developed countries such as U.S and U.K., where its formation is compulsory. Furthermore, intensive government control and intervention impose additional complexity to the functioning of the audit committee of the Chinese board (Pan, Xia \& Yu, 2008; Zhang \& Wang, 2010).

The preceding narrative raises questions. First, if the stated purpose of the cited legislation is to protect investors, does the audit committee of the board play a role in reducing agency costs? Second, partial ownership of Chinese firms means that the State potentially controls operations which also suggest that it may play an important role in corporate governance. Therefore, does the nature of the firm's ownership/management structure matter? Third, both pieces of legislation ascribe importance to directors being "independent" with at least one audit committee member deemed a "financial expert". However, nothing about the composition of the audit committee is ascribed to either piece of legislation even though there is increasing awareness throughout the business and academic communities that women directors further the board's governance function (Burke \& Mattis, 2000). Thus, does this recognition of the importance of gender for the board and its committees extend to Chinese companies? We address the question whether women, who serve on the audit committee, can play a role in reducing audit fees - our proxy for agency costs - of Chinese companies. 
This paper uses a sample of China's A-share listed companies during the period 2004 to 2007. We use number of female members, presence of at least one female member, and percentage of female members on the audit committee as our measures for diversity. This study contributes to the literature in four ways. First, prior research on audit committees in China mainly focuses on those factors that influence the formation of audit committees and their characteristics, thus ignoring the issue of gender diversity. We study that issue in the special institutional background of China where audit committee formation is voluntary and find that diversity leads to lower audit fees, the same as Ittonen, Miettinen and Vähämaa (2010) document using U.S. data. This finding suggests that even though differences exist in institutional and business conditions between China and the U.S., the public's perception of the contribution that Chinese business women provide is similar to that realized by American women. Second, after considering the influence of ownership structure and management control on the governance function of audit committees, we show that the negative relationship between diversity and audit fees is significantly greater in non-state enterprises than that in state-owned enterprises; however, the negative relationship of diversity and audit fees exists only when management control is weak. Third, our results suggest that after controlling for ownership structure and management control, there is a significantly negative relationship between diversity and audit fees in both state-owned and non-state firms when management is weak but when it is strong, gender diversity is not significantly negatively related to audit fees in either state-owned or non-state enterprises.

\section{Literature Review and Hypotheses}

Audit fees are determined both by client demand and the supply of this service by external auditors (Abbott, Parker, Peters \& Raghunandan, 2003; Collier \& Gregory, 1996; Goddard \& Masters, 2000; Goodwin-Stewart \& Kent, 2006). One school of thought holds that audit committees require higher quality audits, thus necessitating more audit hours expended along with greater assurances from external auditors that financial statements are stated in accordance with specified criteria (Abbott,et al.2003). Conversely, supply-side arguments suggest that the more effective the audit committee, the better the company's internal controls and the more reliable the firm's accounting systems (Gul \&Tsui, 1997; Mitra, Hossain \&Deis, 2007; Tsui, Jaggi\& Gul,2001).

The literature on audit committees mainly focuses on the characteristics (e.g. independence, expertise and activity) and association between audit committee quality, auditor independence and internal control (Bedard, Chtourou \& Courteau, 2004; Carcello \& Neal, 2000; Zhang, Zhou \& Zhou,2007). Recently, some studies find that gender diversity of audit committees plays an important role in corporate governance (Gavious, Segev\& Yosef, 2012; Ittonenet al. 2010; Thiruvadi \& Huang, 2011), but these studies are based on U.S. data and generally do not examine situations unique to emerging and transitional nations, thus their findings may not be applicable to Chinese firms.

The primary focus of Chinese academic studies pertaining to the audit committee is which factors influence the formation (Xia, 2005; Xiang, 2012; Xiang, Gan \& Wang, 2010) and characteristics (Wang, Zhang \&Gao, 2008; Wang, Wang \& Wu, 2006). Audit fees have been 
associated with the ratio of independent to non-independent directors ( $\mathrm{Li} \&$ Wang, 2006). Large boards pay more for auditing while State ownership and top executive duality (CEO and board chair being the same individual) are associated with lower audit fees (Cai, 2007). Cai also finds that non-State ownership with moderate managerial stock ownership reduces audit fees. He and Liu (2015) show that companies with management deemed as having high ability, as measured by the MA score (which is partitioned from total efficiency of the firm and the manager), pay less for auditing. The purpose of this paper is to extend that research stream by investigating whether gender diverse audit committees have a significant effect on the audit feesof Chinese companies, after controlling for ownership typeand management control.

\subsection{Gender Diversity of Audit Committees and Audit Fees}

Many authors using data from the developed world have also addressed research questions pertaining to the efficacy of the board (Fondas \& Sassalos, 2000; Huse \& Grethe-Solberg, 2006; Miller \&del Carmen Triana, 2009; Nielson \&Huse, 2010) and audit committee when women are members. Stewart and Munro (2007) argue that female representatives on audit committees demonstrate superior communication skills and are better prepared for meetings. In comparison to committees that are totally male, a woman's presence makes members more diligent (Thiruvadi, 2012) and reduces fees (Ittonenet al. 2010). Kuang and Chen (2011) suggest that a feminine presence on the Chinese corporate board is associated with demands for higher quality external auditing. As the percentage of female board members increases, there are more discussions at board meetings, the discussions are smoother and directors pay closer attention to the interests of other stakeholders and not just stockholders; thus corporate reputation improves (Gao\& Zhang, 2011). We argue that having women on the audit committee can significantly increase the quality of financial reporting and the efficacy of internal control, thereby lowering audit fees in Chinese firms like elsewhere. Thus,our hypothesis is:

\section{Hypothesis 1: The gender diversity of audit committees is negatively related to audit fees.}

\subsection{Gender Diversity of Audit Committees, Ownership Structure and Audit Fees}

Durnev and Kim (2005) argue that major shareholders with different characteristics may have different incentive mechanisms. State-owned listed companies are essentially controlled by and extensions of government with their decisions influenced by State considerations such as those related to job security, tax revenues and social stability (Chen, Firth, Gao \&Rui, 2006). The non-transferability of state-owned property rights leads to large transaction costs for shareholders or management to liquidate ownership interests and thus, major shareholders of state-owned companies have increased incentive to encroach upon profits at the expense of minority shareholders. In contrast, stockholders of non-state companies in China seem more unified in striving towards the goal of maximizing shareholder wealth.

State ownership is generally regarded as inefficient (Boycko, Shleifer \&Vishny, 1995; Roland,2000). The government is the controlling shareholder and its intervention may lead to tunneling, which means that controlling shareholders encroach upon company assets and 
profits for their own benefit. In China, the government takes responsibility for the failure of state-owned companies; companies do not bear the risks. Non-state companies do not have this government backstop, thus need to be more cognizant about projects undertaken and risks assumed. Xia and Fang (2005) find that government control, especially at county and city levels, has a negative impact on corporate value. In contrast, Xu and Chen(2003) document that listed non-state companies have greater corporate value, larger profits and are more flexible in operation. $\mathrm{Xu}$ and Chen also find the efficacy of corporate governance is higher - senior management subjected to more rigorous supervision within and more scrutiny from outside the company. Liu, Ye and Liao (2014) find that women directors significantly increase financial performance in non-state firms while performance in state-owned firms is not associated with female directors.

It appears that risks confronted and management motives may differ between state-owned vis-à-vis non-state organizations. How does this ownership dichotomy affect those women who serve as directors on the audit committee? We argue that due to the government intervention, the female members on a state-owned corporate audit committee may not perform their responsibilities as effectively as their female counterparts on non-state firms. Hence control risks, which are an important source of audit risks, increase. Our hypothesis is:

Hypothesis 2: The negative relationship between the gender diversity of audit committees and audit fees is greater in non-state enterprises than that realized in state-owned enterprises.

\subsection{Management Control, Gender Diversity and Audit Fees}

One function of the board is to emplace mechanisms that minimize conflict between management and shareholders (Jensen \& Meckling, 1976). Although the board supposedly monitors management, managers may still pursue their own interests by affecting its composition (Mizruchi, 1983; Weisbach, 1988). Vance (1983) argues that when management controls the board, it is in fact supervising itself which weakens the board. If the company's chief executive officer simultaneously serves as board chair, it is harder for boards to function (Lipton \&Lorsch, 1992). With increased management control, the power balance between the two sides weakens. Increased control by management also negatively affects the independence of its audit committee (Ruiz-Barbadillo, Biedma-Lopez \& Gomez-Aguilar, 2007). In China, the CEO is usually appointed by the controlling shareholder (the State if the company is state-owned) and oftentimes also chairs the board, thus weakening the board's supervisory role.

Gender is another type of power relationship affected by the corporate environment in which it exists (Scott, 1999). When management control is strong, traditional feminine characteristics such as conservatism and obedience may reduce a woman's influence on the committee and may diminish her ability to positively affect corporate governance. We argue that with stronger management control, fewer women are appointed as audit committee members further weakening its supervisory function. This lowers the quality of financial reporting and thus, increases auditing hours and risk assessment. Our hypothesis is:

Hypothesis 3: The negative relationship between the gender diversity of audit committees and 
audit fees is greater in companies where management control is weak than in companies where management control is strong.

\section{Research Design}

The data herein is obtained from the CSMAR (China Security Market Accounting Research) database except for that pertaining to audit committees which was collected by hand for the period from 2004 to 2007. Reliable data on control/ownership of listed companies is not available prior to 2004 . The 2008 U.S. subprime mortgage financial crisis affected Chinese companies including audit fees, thus we exclude companies beginning in 2008 and thereafter. ${ }^{1}$

We screened the sample as follows: first, we reject firms with insufficient information about their audit committees; second, we omit companies that do not have actual controllers; third, we exclude firms with insufficient financial data. We are left with 2,114 observations, including 359 (2004), 483 (2005), 526 (2006), and 746 in 2007. Our sample is subdivided into the type ofcontrollers, resulting in 1,446 state-owned and 668 non-state observations. We also divide our sample according to whether the CEO simultaneously serves as chairman of the board. There are 278 observations labeled as having strong management control, i.e., the two positions of CEO and board chair are dually held by the same individual, and 1,816 observations with weak management control (no duality).

We use the following model to investigate the influence of gender diversity on audit fees:

$A F E E=\beta_{0}+\beta_{1} G E N D E R+\beta_{2} C S I Z E+\beta_{3} R E C+\beta_{4} I N V E N+\beta_{5} L E V+\beta_{6} C F O+\beta_{7} L O S S+$ $\beta_{8} S I Z E+\varepsilon$

where AFEE is the dependent variable specified as the natural log of domestic audit fees. GENDER is the explanatory variable representing the audit committee's gender diversity. As per Ittonen, et al. (2010) and Thiruvadi and Huang (2011), we use three proxies to measure diversity: FSIZE denotes the number of women members; FEM is a dummy variable set to 1 if there is at least one female on the audit committee; and FPCT denotes the percentage of female members to total number of directors on the committee.

Based on prior literature (Abbott,et al. 2003; Ittonen, et al. 2010; Mitra, et al. 2007; Thiruvadi \& Huang, 2011), control variables are defined as follows: CSIZE is a measure of the total number of audit committee members; REC is the ratio of fiscal year end (hereafter FYE) receivables to total assets; INVEN is the ratio of FYE inventories to total assets; LEV is the asset-liability ratio specified as FYE total debt to total assets; CFO denotes FYE net cash flow from operations to total assets; LOSS is a dummy variable set to 1 if the firm has incurred a loss, 0 otherwise; SIZE is measured as the natural log of FYE assets.

\section{Results and Discussion}

Table 1, Panel A presents descriptive statistics. The mean and median values of AFEE are 13.061 and 13.017, respectively; the mean values of FSIZE, FEM and FPCT are 0.46, 0.37 and 0.131, which differ from Thiruvadi and Huang (2011), who report 0.22, 0.20 and 0.06 for the same metrics, suggesting that the gender diversity of Chinese listed companies is larger 
than that of the S\&P Small Cap 600 firms. The mean and median values of CSIZE are 3.6 and 3.0, respectively, differing from Ittonen, et al. (2010) who report 4.143 and 4.0 for S\&P 500 firms, suggesting smaller sized audit committees for Chinese firms.

Panel B shows subsamples of state-owned and non-state enterprises. The 13.103 mean value shown for the audit expense (AFEE) incurred by state-owned companies is significantly larger than the 12.971 shown for non-state firms $(t=5.095 ; \mathrm{p}=0.000)$. Our metrics for female membership on the audit committee (FSIZE, FEM, FPCT) are 0.46, 0.37 and 0.125 for state-owned organizations and $0.48,0.38$ and 0.146 for publicly-owned companies. Only FPCT - the percentage of women serving as audit committee members - has a statistically significant difference $(\mathrm{t}=-2.144, \mathrm{p}=0.032)$. The results suggest that state-owned firms pay more for auditing and have fewer women sitting on the audit committee $-\mathrm{a}$ finding consistent with the hypotheses.

\begin{tabular}{|c|c|c|c|c|c|c|c|c|c|c|c|}
\hline \multicolumn{12}{|c|}{ 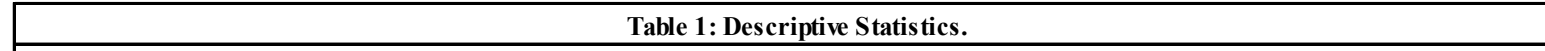 } \\
\hline \multicolumn{12}{|c|}{ Panel a: Sample statistics N=2114 } \\
\hline Variable & AFEE & FSIZE & FEM & FPCT & CSIZE & REC & INVEN & LEV & $\mathrm{CFO}$ & LOSS & SIZE \\
\hline Mean & 13.061 & 0.460 & 0.370 & 0.131 & 3.600 & 0.117 & 0.169 & 0.985 & 0.043 & 0.120 & 21.363 \\
\hline Median & 13.017 & 0.000 & 0.000 & 0.000 & 3.000 & 0.093 & 0.140 & 0.528 & 0.052 & 0.000 & 21.269 \\
\hline Stdev & 0.556 & 0.678 & 0.484 & 0.197 & 1.315 & 0.108 & 0.143 & 19.077 & 0.552 & 0.320 & 1.182 \\
\hline \multicolumn{12}{|c|}{ Panel b: State-owned and non-state companies } \\
\hline \multirow[b]{2}{*}{ Variable } & \multicolumn{3}{|c|}{ State-owned $(\mathrm{N}=1146)$} & \multicolumn{3}{|c|}{ Non-state-owned $(\mathrm{N}=668)$} & \multicolumn{2}{|c|}{ Difference } & & & \\
\hline & Mean & Median & Std. & Mean & Median & Std. & Mean & t-statistic & & & \\
\hline AFEE & 13.103 & 13.017 & 0.553 & 12.971 & 12.899 & 0.539 & $0.132 * *$ & 5.095 & & & \\
\hline FSIZE & 0.460 & 0.000 & 0.676 & 0.480 & 0.000 & 0.683 & -0.020 & -0.829 & & & \\
\hline FEM & 0.370 & 0.000 & 0.483 & 0.380 & 0.000 & 0.487 & -0.010 & -0.712 & & & \\
\hline FPCT & 0.125 & 0.000 & 0.188 & 0.146 & 0.000 & 0.216 & -0.021 & -2.144 & & & \\
\hline \multicolumn{12}{|c|}{ Panel c: Strong and weak management control } \\
\hline \multirow[b]{2}{*}{ Variable } & \multicolumn{3}{|c|}{ Strong management $(\mathrm{N}=278)$} & \multicolumn{3}{|c|}{ Weak Management $(\mathrm{N}=1816)$} & \multicolumn{2}{|c|}{ Difference } & & & \\
\hline & Mean & Median & Std. & Mean & Median & Std. & Mean & $\mathrm{t}$-statistic & & & \\
\hline AFEE & 12.999 & 12.899 & 0.544 & 13.069 & 13.017 & 0.558 & $-0.070 \dagger$ & -1.956 & & & \\
\hline FSIZE & 0.450 & 0.000 & 0.677 & 0.470 & 0.000 & 0.679 & -0.020 & -0.396 & & & \\
\hline FEM & 0.350 & 0.000 & 0.476 & 0.380 & 0.000 & 0.485 & -0.030 & -1.090 & & & \\
\hline FPCT & 0.128 & 0.000 & 0.202 & 0.132 & 0.000 & 0.197 & -0.004 & -0.337 & & & \\
\hline
\end{tabular}

Companies differentiated by strength of management are shown in Panel C. Companies with strong management control report a mean value for AFEE of 12.999 whereas audit expense for those firms with weak management is 13.069 -a statistically significant difference $(\mathrm{t}=$ $-1.956, \mathrm{p}=0.051)$. The numbers for the three variables representing a woman's presence on the audit committee are not significantly different between groups. The results suggest that what strong management is willing to pay for auditing is not dependent upon the composition of the committee.

Table 2 presents multiple regression results. All gender coefficients are negative and significant at the 0.05 level - a finding consistent with H1 that fees decline with a woman's presence $\left(\beta_{\mathrm{FEM}}=-0.047, \mathrm{p}=0.014\right)$ on the audit committee. Similarly, fees decline as the number of females $\left(\beta_{\mathrm{FSIZE}}=-0.034, \mathrm{p}=0.015\right)$ or as the ratio of female to male committee members increases $\left(\beta_{\mathrm{FPCT}}=-0.015, \mathrm{p}=0.013\right)$ after controlling for other variables shown to affect fees. 


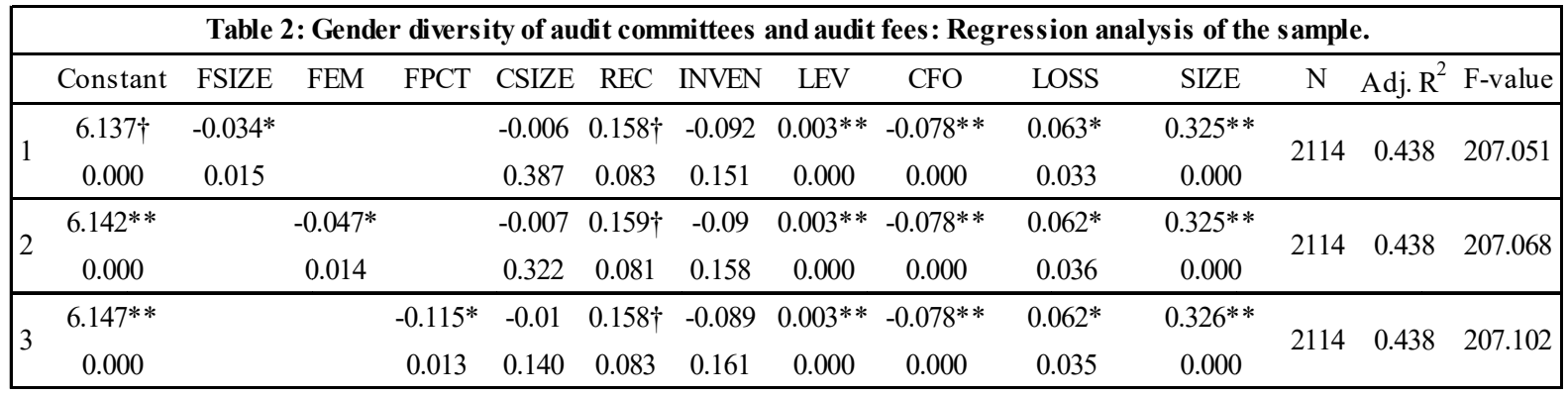

$(p=0.10 \dagger ; p=0.05 * ; p=0.01 * *)$

The significance of the control variables suggests it is more expensive to audit large corporations (SIZE); firms that are highly leveraged (LEV); and companies that have recently experienced a loss (LOSS). As net cash flow from operations (CFO) increases, the cost of auditing declines. There is some indication (at the $10 \%$ level) that as the proportion of receivables-to-assets (REC) increases, so too does the cost of auditing.

Regression results for the second hypothesis pertaining to state-owned versus publicly-owned companies are shown in Table 3. Models (1), (2) and (3) test the association between gender diversity and audit fees in state-owned enterprises. Only model (3), in which FPCT is -0.118 $(p=0.035)$ suggests that the percentage of female audit committee members helps reduce audit fees. This demonstrates that any fee-effects arising from gender diversity are limited in state-owned firms. Models (4), (5) and (6) report tests of this diversity/audit fees relationship in non-state enterprises. Our proxies for female membership on the committee $\left(\beta_{\mathrm{FSIZE}}=-0.07\right.$, $\left.p=0.007 ; \beta_{\mathrm{FEM}}=-0.086, p=0.018 ; \beta_{\mathrm{FPCT}}=-0.159, \mathrm{p}=0.048\right)$ are all negative and significant, suggesting that fees decrease when women sit on their audit committees. The evidence supports $\mathrm{H} 2$ that gender diverse committees in publicly-held companies have smaller audit fees than those in state-owned companies.

Table 3: Regression anakysis of subs amples by ownership structure.

\begin{tabular}{|c|c|c|c|c|c|c|c|c|c|c|c|c|c|c|}
\hline \multicolumn{15}{|c|}{ Panel a: State-omned Companies } \\
\hline & Constant & FSIZE & FEX & FPCT & CSIZE & REC & DIE: & LEV & CFO & Loss & SIZE & $x$ & Adj $R^{2}$ & Fratue \\
\hline \multirow[t]{2}{*}{1} & $5.60^{* *}$ & -0.022 & & & 0004 & $0.441^{* *}$ & $-0.186^{*}$ & $0006^{*}$ & $-0.078 *$ & 0.038 & $0.345^{* *}$ & \multirow{2}{*}{1446} & \multirow{2}{*}{0.49} & \multirow{2}{*}{175.66} \\
\hline & 0.000 & 0.165 & & & 0.607 & 0000 & 0.017 & 0.000 & 0.000 & 0.285 & 0.000 & & & \\
\hline \multirow[t]{2}{*}{2} & $5.61^{* *}$ & & -0.305 & & 0004 & $0.441^{* *}$ & $-0.186^{*}$ & $00086^{*}$ & $-0.077 *$ & 0.038 & $0.345^{* 7}$ & \multirow{2}{*}{1446} & \multirow{2}{*}{0.49} & \multirow{2}{*}{175.81} \\
\hline & 0.000 & & 0.110 & & 0.621 & 0000 & 0.017 & 0.033 & 0.000 & 0.287 & 0.000 & & & \\
\hline \multirow[t]{2}{*}{3} & $5.62^{* *}$ & & & $-0.118^{*}$ & 0002 & $0.442^{* *}$ & $-0.189^{*}$ & $0006^{*}$ & $-0.077 *$ & 0.037 & $0.345^{* *}$ & \multirow{2}{*}{1446} & \multirow{2}{*}{0.49} & \multirow{2}{*}{17628} \\
\hline & 0.000 & & & 0.035 & 0.836 & 0000 & 0.015 & 0.032 & 0.000 & 0.303 & 0.000 & & & \\
\hline \multicolumn{15}{|c|}{ Panel b: Jon-state Companies } \\
\hline \multirow[t]{2}{*}{4} & $6.85 * *$ & $-0.07 * *$ & & & $-0.027 t$ & -0.178 & -0.015 & $0.003 * *$ & 0.090 & $0.103 t$ & $0.298 * *$ & \multirow{2}{*}{668} & \multirow{2}{*}{0.32} & \multirow{2}{*}{40.06} \\
\hline & 0.000 & 0.007 & & & 0050 & 0.228 & 0.899 & 0.000 & 0.620 & 0.051 & 0.000 & & & \\
\hline \multirow[t]{2}{*}{5} & $6.84 *$ & & $-0.086^{*}$ & & $-0.030^{*}$ & -0.171 & -0.011 & $0.003^{* *}$ & 0.081 & $0.096 t$ & $0.299^{* *}$ & \multirow{2}{*}{688} & \multirow{2}{*}{0.32} & \multirow{2}{*}{39.73} \\
\hline & 0.000 & & 0.018 & & 0035 & 0.247 & 0.928 & 0.000 & 0.654 & 0.080 & 0.000 & & & \\
\hline \multirow[t]{2}{*}{6} & $6.83^{* *}$ & & & $-0.159 *$ & $-0.037^{* *}$ & -0.176 & -0.014 & $0.003^{* *}$ & 0.076 & $0.100 t$ & $0300^{* *}$ & \multirow{2}{*}{668} & \multirow{2}{*}{0.32} & \multirow{2}{*}{39.41} \\
\hline & 0.000 & & & 0.048 & 0010 & 0.236 & 0.907 & 0.000 & 0.676 & 0.070 & 0.000 & & & \\
\hline
\end{tabular}

Regardless of ownership structure, SIZE and LEV have significant impact on fees. Interestingly, REC, INVEN and CFO are significant for state-owned firms but not public 
companies (panel a). One plausible explanation is that receivables in state-owned firms are subject to government intervention. Transactions have an added element of complexity resulting in larger bad debt ratios. Other implicit guarantees also exist in state-owned companies, thus a large inventory ratio does not necessarily suggest problems with financial performance. And with official administrative posts/ranks, management has motive to reduce the risks of cash flows from operations so as to improve its political stature.

LOSS and CSIZE are non-state variables of interest (panel b). When firms incur losses, state-owned companies avoid 'special treatment', i.e., the possibility of delisting, by China's Securities Regulatory Commission by receiving financial subsidies whereas their non-state counterparts can protect themselves from punishment only through earnings. This increases risk and audit expense. Less government intervention in publicly-owned firms may also suggest that the audit committee can more effectively advise management as committee size increases, thus reducing audit fees.

Table 4 shows results divided by strength of management. Models (1), (2) and (3) show the association between a woman's presence on the committee and audit expense in firms with strong management, previously defined as those companies in which the CEO and chairman of the board are the same person. A gender diverse committee does not function to reduce fees when management is strong. Models (4), (5) and (6) report the relationship between gender diversity and fees in companies with weak management, i.e., the CEO and board chairman are two different individuals. Negative and significant results appear in the three models $\left(\beta_{\mathrm{FSIZE}}=-0.033, \mathrm{p}=0.022 ; \beta_{\mathrm{FEM}}=-0.045, \mathrm{p}=0.027 ; \beta_{\mathrm{FPCT}}=-0.109, \mathrm{p}=0.027\right)$, suggesting that fees decline when management is weak and women serve as committee members. The evidence supports $\mathrm{H} 3$ that gender diverse committees help to reduce audit fees in a managerial framework designated as having weak management control.

\begin{tabular}{|c|c|c|c|c|c|c|c|c|c|c|c|c|c|c|}
\hline \multicolumn{15}{|c|}{ Panel a: Companies with strong management control } \\
\hline & Constant & FSIZE & FEM & FPCT & CSIZE & REC & INVEN & LEV & $\mathrm{CFO}$ & LOSS & SIZE & $\mathrm{N}$ & Adj. $R^{2}$ & F-value \\
\hline \multirow[t]{2}{*}{1} & $7.24 * *$ & -0.024 & & & -0.009 & -0.071 & -0.124 & $0.002 * *$ & $-0.070 * *$ & 0.032 & $0.277 * *$ & \multirow{2}{*}{278} & \multirow{2}{*}{0.39} & \multirow{2}{*}{23.049} \\
\hline & 0.000 & 0.531 & & & 0.694 & 0.718 & 0.527 & 0.000 & 0.000 & 0.682 & 0.000 & & & \\
\hline \multirow[t]{2}{*}{2} & $7.24 * *$ & & -0.026 & & -0.009 & -0.066 & -0.118 & $0.002 * *$ & $-0.070 * *$ & 0.032 & $.277 * *$ & \multirow{2}{*}{278} & \multirow{2}{*}{0.39} & \multirow{2}{*}{23.012} \\
\hline & 0.000 & & 0.640 & & 0.670 & 0.738 & 0.550 & 0.000 & 0.000 & 0.688 & 0.000 & & & \\
\hline \multirow[t]{2}{*}{3} & $7.25 * *$ & & & -0.104 & -0.011 & -0.066 & -0.117 & $0.002 * *$ & $-0.070 * *$ & 0.032 & $.277 * *$ & \multirow{2}{*}{278} & \multirow{2}{*}{0.39} & \multirow{2}{*}{23.106} \\
\hline & 0.000 & & & 0.414 & 0.609 & 0.737 & 0.550 & 0.032 & 0.000 & 0.683 & 0.000 & & & \\
\hline \multicolumn{15}{|c|}{ Panel b: Companies with weak management control } \\
\hline \multirow[t]{2}{*}{4} & $5.56^{* *}$ & $-0.033^{*}$ & & & -0.007 & $0.281 * *$ & -0.107 & $0.108 * *$ & -0.116 & 0.034 & $0.349 * *$ & \multirow{2}{*}{1816} & \multirow{2}{*}{0.46} & \multirow{2}{*}{193.047} \\
\hline & 0.000 & 0.022 & & & 0.330 & 0.007 & 0.133 & 0.000 & 0.310 & 0.298 & 0.000 & & & \\
\hline \multirow[t]{2}{*}{5} & $5.56^{* *}$ & & $-0.045^{*}$ & & -0.008 & $0.280 * *$ & -0.107 & $0.108^{* *}$ & -0.116 & 0.032 & $0.349 * *$ & \multirow{2}{*}{1816} & \multirow{2}{*}{0.46} & \multirow{2}{*}{192.957} \\
\hline & 0.000 & & 0.027 & & 0.260 & 0.007 & 0.134 & 0.000 & 0.310 & 0.316 & 0.000 & & & \\
\hline \multirow[t]{2}{*}{6} & $5.57 * *$ & & & $-0.109^{*}$ & -0.012 & $0.280^{* *}$ & -0.105 & $0.108^{* *}$ & -0.118 & 0.033 & $0.350^{* *}$ & \multirow{2}{*}{1816} & \multirow{2}{*}{0.46} & \multirow{2}{*}{192.968} \\
\hline & 0.000 & & & 0.027 & 0.117 & 0.007 & 0.139 & 0.000 & 0.301 & 0.312 & 0.000 & & & \\
\hline
\end{tabular}

SIZE and LEV remain significant regardless of sample groupings. REC is important for 
companies with weak management control whereas CFO is significant in companies with strong management. Our suspicion is that the complexity of receivable and the risk of uncollectibleare larger in firms with weak management. This exposes the auditors to increased risk. CFO is negative, which may indicate that strong management is more capable at controlling cash flows from operations, lowering audit risks.

\section{Further Analysis}

In further discussion, we separate the sample first into companies with strong and weak management and then each management group into state-owned vis-à-vis publicly-owned companies in order to examine when management control varies, whether the negative relationship between gender and audit fees is affected by ownership.

Table 5 reports that there are no gender effects arising from a female presence on the audit committee when management control is strong regardless of ownership. As before, fees increase with the size of the firm. Interestingly, a dichotomy exists for cash flow from operations. When the state shares ownership, an increase in CFO reduces auditing costs as expected. In contrast, expense increases with $\mathrm{CFO}$ for publicly-held corporations. One plausible explanation is that strong management pursues its own interests rather than maximize the value of cash flow from operations, increasing audit risks and incurring larger audit expenses. The previously identified positive relationship between leverage and auditing costs is again present but only for non-state companies. Government implicit guarantees do not extend to publicly-held firms. Thus, creditors demand higher quality and more expensive auditing as non-state enterprises increase their debt burden.

\begin{tabular}{|c|c|c|c|c|c|c|c|c|c|c|c|c|c|c|}
\hline \multicolumn{15}{|c|}{ Table 5: Companies with strong management control. } \\
\hline & ate-owners & & & & & & & & & & & & & \\
\hline & Constant & FSIZE & FEM & FPCT & CSIZE & REC & INVEN & LEV & $\mathrm{CFO}$ & LOSS & SIZE & $\mathrm{N}$ & Adj. $\mathrm{R}^{2}$ & F-value \\
\hline \multirow[t]{2}{*}{1} & $6.40 * *$ & -0.008 & & & -0.001 & -0.189 & -0.143 & 0.073 & $-0.087 * *$ & 0.071 & $0.312 * *$ & \multirow{2}{*}{150} & \multirow{2}{*}{0.45} & \multirow{2}{*}{16.465} \\
\hline & 0.000 & 0.900 & & & 0.968 & 0.610 & 0.638 & 0.545 & 0.000 & 0.589 & 0.000 & & & \\
\hline \multirow[t]{2}{*}{2} & $6.42 * *$ & & -0.005 & & -0.003 & -0.204 & -0.141 & 0.074 & $-0.087 * *$ & 0.071 & $.311 * *$ & \multirow{2}{*}{150} & \multirow{2}{*}{0.45} & \multirow{2}{*}{16.462} \\
\hline & 0.000 & & 0.949 & & 0.925 & 0.589 & 0.643 & 0.541 & 0.000 & 0.586 & 0.000 & & & \\
\hline \multirow[t]{2}{*}{3} & $6.40 * *$ & & & -0.048 & -0.002 & -0.180 & -0.143 & 0.072 & $-0.087 * *$ & 0.071 & $.312 * *$ & \multirow{2}{*}{150} & \multirow{2}{*}{0.45} & \multirow{2}{*}{16.474} \\
\hline & 0.000 & & & 0.820 & 0.956 & 0.627 & 0.637 & 0.550 & 0.000 & 0.586 & 0.000 & & & \\
\hline \multicolumn{15}{|c|}{ Panel b: Public ownership } \\
\hline 4 & $8.15 * *$ & -0.062 & & & -0.027 & 0.103 & 0.056 & $0.002 * *$ & $0.718^{*}$ & -0.003 & $0.235^{* *}$ & \multirow{2}{*}{1816} & \multirow{2}{*}{0.46} & \multirow{2}{*}{193.047} \\
\hline & 0.000 & 0.229 & & & 0.360 & 0.670 & 0.831 & 0.006 & 0.049 & 0.975 & 0.000 & & & \\
\hline \multirow[t]{2}{*}{5} & $8.16^{* *}$ & & -0.084 & & -0.028 & 0.115 & 0.079 & $0.002 * *$ & $0.702 \dagger$ & -0.009 & $0.234 * *$ & \multirow{2}{*}{1816} & \multirow{2}{*}{0.46} & \multirow{2}{*}{192.957} \\
\hline & 0.000 & & 0.276 & & 0.345 & 0.634 & 0.768 & 0.006 & 0.054 & 0.933 & 0.000 & & & \\
\hline \multirow[t]{2}{*}{6} & $8.18 * *$ & & & -0.218 & -0.034 & 0.116 & 0.070 & $0.002 * *$ & $0.713^{*}$ & -0.009 & $0.234 * *$ & \multirow{2}{*}{1816} & \multirow{2}{*}{0.46} & \multirow{2}{*}{192.968} \\
\hline & 0.000 & & & 0.166 & 0.258 & 0.630 & 0.790 & 0.006 & 0.050 & 0.931 & 0.000 & & & \\
\hline
\end{tabular}

Table 6 shows the results of our gender investigations when management control is weak. For state-owned companies, neither the presence (FEM) nor number (FSIZE) of females holding a committee seat is significant. However, there is a significant and negative relationship between the ratio of women to men $\left(\beta_{\mathrm{FPCT}}=-0.127, \mathrm{p}=0.030\right)$ and audit fees.Large companies and levered firms increase expenditures for auditing. Panel $b$ reports both number of women $\left(\beta_{\mathrm{FSIZE}}=-0.062, \mathrm{p}=0.035\right)$ and their presence $\left(\beta_{\mathrm{FEM}}=-0.069, \mathrm{p}=0.085\right)$ reduces fees for non-state companies. As the total number of committee members increase (CSIZE), 
fees decline. We suppose this is true because with more eyes watching management, audit risks and expenses decline.

\begin{tabular}{|c|c|c|c|c|c|c|c|c|c|c|c|c|c|c|}
\hline \multicolumn{15}{|c|}{ Table 6: Companies with weak management control. } \\
\hline \multicolumn{15}{|c|}{ Panel a: State-ownership } \\
\hline & Constant & FSIZE & FEM & FPCT & CSIZE & REC & INVEN & LEV & $\mathrm{CFO}$ & LOSS & SIZE & $\mathrm{N}$ & Adj. $R^{2}$ & F-value \\
\hline \multirow[t]{2}{*}{1} & $5.32 * *$ & -0.023 & & & 0.003 & $0.571^{* *}$ & $-0.209 *$ & $0.079 \dagger$ & -0.128 & 0.032 & $0.358 * *$ & \multirow{2}{*}{1277} & \multirow{2}{*}{0.50} & \multirow{2}{*}{159.92} \\
\hline & 0.000 & 0.169 & & & 0.741 & 0.000 & 0.015 & 0.072 & 0.356 & 0.393 & 0.000 & & & \\
\hline \multirow[t]{2}{*}{2} & $5.33^{* *}$ & & -0.036 & & -0.002 & $0.568 * *$ & $-0.211^{*}$ & $0.079 \dagger$ & -0.128 & 0.032 & $0.357^{* *}$ & \multirow{2}{*}{1277} & \multirow{2}{*}{0.50} & \multirow{2}{*}{159.05} \\
\hline & 0.000 & & 0.118 & & 0.766 & 0.000 & 0.014 & 0.073 & 0.354 & 0.401 & 0.000 & & & \\
\hline \multirow[t]{2}{*}{3} & $5.35^{* *}$ & & & $-0.127^{*}$ & 0.002 & $0.570 * *$ & $-0.214 *$ & $0.079 \dagger$ & -0.134 & 0.030 & $0.357^{* *}$ & \multirow{2}{*}{1277} & \multirow{2}{*}{0.50} & \multirow{2}{*}{159.62} \\
\hline & 0.000 & & & 0.030 & 0.996 & 0.000 & 0.013 & 0.071 & 0.332 & 0.426 & 0.000 & & & \\
\hline \multicolumn{15}{|c|}{ Panel b: Public ownership } \\
\hline \multirow[t]{2}{*}{4} & $5.61^{* *}$ & $-0.062 *$ & & & $-0.034^{*}$ & -0.123 & -0.008 & $0.109^{* *}$ & 0.042 & 0.085 & $0.354^{* *}$ & \multirow{2}{*}{539} & \multirow{2}{*}{0.36} & \multirow{2}{*}{39.287} \\
\hline & 0.000 & 0.035 & & & 0.035 & 0.500 & 0.952 & 0.000 & 0.838 & 0.178 & 0.000 & & & \\
\hline \multirow[t]{2}{*}{5} & $5.59 * *$ & & $-0.069 \dagger$ & & $-0.038^{*}$ & -0.117 & -0.007 & $0.109 * *$ & -0.049 & 0.079 & $0.356^{* *}$ & \multirow{2}{*}{539} & \multirow{2}{*}{0.36} & \multirow{2}{*}{38.992} \\
\hline & 0.000 & & 0.085 & & 0.019 & 0.521 & 0.956 & 0.000 & 0.811 & 0.209 & 0.000 & & & \\
\hline \multirow[t]{2}{*}{6} & $5.56^{* *}$ & & & -0.114 & $-0.043^{*}$ & -0.122 & -0.008 & $0.110^{* * *}$ & -0.055 & 0.084 & $0.357 * *$ & \multirow{2}{*}{539} & \multirow{2}{*}{0.36} & \multirow{2}{*}{38.717} \\
\hline & 0.000 & & & 0.208 & 0.007 & 0.505 & 0.954 & 0.000 & 0.786 & 0.185 & 0.000 & & & \\
\hline
\end{tabular}

The combined results suggest that the female-male composition of the audit committee does not matter when management control is strong. When control is weak, it appears that women matter - audit fees decline - for both state-owned and non-state companies.

\section{Conclusion}

This paper investigates whether the supervision function and governance of audit committees have an influence on fees from the perspective of gender diversity. We use number of female members, presence of at least one female member, and percentage of female committee members as measures to examine the relationship between gender diversity and audit fees for Chinese companies, taking into consideration the effects of both ownership structure and management control. The conclusion is that gender diversity is significant and negatively related to audit fees, and that such a relationship is greater in non-state enterprises than that in state-owned enterprises. Furthermore, the negative relationship of gender diversity and audit fees exists only when management control is weak. In further analysis, results show that when management control is weak, gender diversity is negatively related to fees in both state-owned enterprises and non-state enterprises, and when management control is strong, gender diversity is not related to fees in either state-owned enterprises or non-state enterprises. Therefore, the governance function of audit committees in China can be improved by increasing gender diversity of audit committees, reforming ownership structure systems in state-owned enterprises and weakening management control.

\section{Acknowledgement}

Data was collected and analyzed for the years 2011-12. Results are similar and available upon request. 


\section{References}

Abbott, L. J., Parker, S., Peters, G. F., \& Raghunandan, K. (2003). The association between audit committee characteristics and audit fees. Auditing: A Journal of Practice \& Theory, 22(2), 17-32.http://dx.doi.org/10.2308/aud.2003.22.2.17

Allen, F., Qian, J., \& Qian, M. (2005).Law, finance, and economic growth in China. Journal of Financial Economics, 77, 57-116. http://dx.doi.org/10.1016/j.jfineco.2004.06.010

Bedard, J., Chtourou, S. M., \& Courteau, L. (2004). The effect of audit committee expertise, independence, and activity on aggressive earnings management. Auditing: A Journal of Practice \& Theory, 23(2), 13-35.http://dx.doi.org/10.2308/aud.2004.23.2.13

Boycko, M., Shleifer, A., \& Vishny, R. W. (1997). Privatizing Russia.Boston: MIT Press Books.

Burke, R. J., \& Mattis, M. C. (Eds.). (2000). Women on corporate boards of directors: International challenges and opportunities. Dordrecht, Netherlands: Kluwer Academic Publishers.

Cai, J. F. (2007). Corporate governance, audit risks and audit fees. Auditing Research, 3, 65-71. (In Chinese)

Carcello, J. V., \& Neal, T. L. (2000).Audit committee composition and auditor reporting. The Accounting Review, 75, 453-467. http://dx.doi.org/10.2308/accr.2000.75.4.453

Chen, G., Firth, M., Gao, D. N., \& Rui, O. M. (2006). Ownership structure, corporate governance, and fraud: Evidence from China. Journal of Corporate Finance, 12, 424-448. http://dx.doi.org/10.1016/j.jcorpfin.2005.09.002

Collier, P., \& Gregory, A. (1996).Audit committee effectiveness and the audit fee. European Accounting Review, 5, 177-198.http://dx.doi.org/10.1080/09638189600000012

Durnev, A., \& Kim, E. H. (2005). To steal or not to steal: Firm attributes, legal environment, and valuation. The Journal of Finance, 60, 1461-1493. http://dx.doi.org/10.1111/j.1540-6261.2005.00767.x

Fondas, N., \& Sassalos, S. (2000). A different voice in the boardroom: How the presence of women directors affects board influence over management. Global Focus, 12(2), 13-22.

Gao, Y.,\& Zhang, X. M. (2011). Female directors and corporate governance. Human Resources Management, 4, 33-34. (In Chinese)

Gavious, I., Segev, E., \& Yosef, R. (2012). Female directors and earnings management in high-technology firms. Pacific Accounting Review, 24, 4-32. http://dx.doi.org/10.1108/01140581211221533

Goddard, A. R., \& Masters, C. (2000). Audit committees, Cadbury Code and audit fees: An empirical analysis of UK companies. Managerial Auditing Journal, 15, 358-371. http://dx.doi.org/10.1108/02686900010344638 
Goodwin-Stewart, J., \& Kent, P. (2006). Relation between external audit fees, audit committee characteristics and internal audit.Accounting \& Finance, 46, 387-404. http://dx.doi.org/10.1111/j.1467-629X.2006.00174.x

Gul, F. A., \& Tsui J. S. L. (1997). A test of the free cash flow and debt monitoring hypotheses: Evidence from audit pricing. Journal of Accounting and Economics, 24, 219-237. Available at SSRN: http://ssrn.com/abstract=2696

He, W. F., \& Liu, W. (2015).Management ability and audit fees.Accounting Research 1, 82-89. (In Chinese)http://dx.doi.org/10.3969/j.issn.1003-2886.2015.01.012

Huse, M., \& Grethe-Solberg, A. (2006). Gender-related boardroom dynamics: How Scandinavian women make and can make contributions on corporate boards. Women in Management Review, 21, 113-130. http://dx.doi.org/10.1108/09649420610650693

Ittonen, K., Miettinen, J., \& Vähämaa, S. (2010). Does female representation on audit committees affect audit fees?. Quarterly Journal of Finance and Accounting, 49, 113-139. Retrieved from http://www.jstor.org/stable/23074633

Jensen, M. C.,\&Meckling, W. H. (1976). Theory of the firm: Managerial behavior, agency costs, and ownership structure. Journal of Financial Economics 3, 305-360. http://dx.doi.org/10.1016/0304-405X(76)90026-X

Kuang, X. W., \& Chen, J. (2011). Gender diversity, management control, and auditing demands. Nankai Business Review, 14(6), 48-56. (In Chinese) http://dx.doi.org/10.3969/j.issn.1008-3448.2011.06.006

Li, B. X., \& Wang, P. X. (2006). Board characteristics and audit fee ratio in Chinese listed firms. China Accounting Review, 4(1), 105-117. (In Chinese)

Lin, B. X.,\& Lu, R. (2009). Managerial power, compensation gap, and firm performance: Evidence from Chinese public listed companies.Global Finance Journal, 20, 153-164. http://dx.doi.org/10.1016/j.gfj.2008.12.002

Lipton, M.,\&Lorsch, J. W. (1992).A modest proposal for improved corporate governance. The Business Lawyer, 48, 59-77. Retrieved from http://www.jstor.org/stable/40687360

Liu, B., Ye, J. Z., \& Liao, Y. Y. (2003). An empirical study on factors affecting audit fees: Evidence from Chinese listed companies in 2001. Auditing Research, 1, 44-47. (In Chinese)

Miller, T., \& del Carmen Triana, M. (2009). Demographic diversity in the boardroom: Mediators of the board diversity-firm performance relationship. Journal of Management Studies, 46, 755-786. http://dx.doi.org/10.1111/j.1467-6486.2009.00839.x

Mitra, S., Hossain, M., \& Deis, D. R. (2007). The empirical relationship between ownership characteristics and audit fees. Review of Quantitative Finance and Accounting, 28, 257-285. http://dx.doi.org/10.1007/s11156-006-0014-7 
Mizruchi, M. S. (1983). Who controls whom? An examination of the relation between management and board of directors in large American corporations. Academy of Management Review, 8, 426-435. http://dx.doi.org/10.5465/AMR.1983.4284426

Nielsen, S.,\&Huse, M. (2010). The contribution of women on boards of directors: Going beyond the surface. Corporate Governance: An International Review, 18, 136-148. http://dx.doi.org/10.1111/j.1467-8683.2010.00784.x

Pan, H. B., Xia, X. P., \& Yu, M. G. (2008). Government intervention, political connections, and the mergers of local government-controlled enterprises. Economic Research Journal, 4, 41-52. (In Chinese)

Roland, G. (2000). Transition and economies: Politics, markets and firms. Boston: MIT Press.

Ruiz-Barbadillo, E., Biedma-López, E., \& Gómez-Aguilar, N. (2007). Managerial dominance and audit committee independence in Spanish corporate governance. Journal of Management and Governance, 11, 311-352. http://dx.doi.org/10.1007/s10997-007-9035-4

Scott, J. W. (1999). Gender and the Politics of History.New York: Columbia University Press.

Stewart, J. \& Munro, L. (2007). The impact of audit committee existence and audit committee meeting frequency on the external audit: Perceptions of Australian auditors. International Journal of Auditing, 51-69. http://dx.doi.org/10.1111/j.1099-1123.2007.00356.x

Thiruvadi, S. (2012). Gender differences and audit committee diligence. Gender in Management: An International Journal, $27, \quad 366-379$. http://dx.doi.org/10.1108/17542411211269310

Thiruvadi, S.,\& Huang, H. W. (2011). Audit committee gender differences and earnings management. Gender in Management: An International Journal, 26, 483-498. http://dx.doi.org/10.1108/17542411111175469

Tsui, J. S., Jaggi, B., \& Gul, F. A. (2001). CEO domination, growth opportunities, and their impact on audit fees. Journal of Accounting, Auditing and Finance, 16, 189-208.

Vance, S. C. (1983). Corporate leadership: Boards, directors, and strategy. New York: McGraw-Hill Companies.

Wang, X. Y., Zhang, S. C., \&Gao, Y. (2008). An empirical study on audit committee characteristics and auditor change. Auditing Research, 4, 87-96. (In Chinese)

Wang, Y., Wang, P. X., \& Wu, Q. H. (2006). The study of the impact of audit committee characteristics on earnings management. Contemporary Economy and Management, 28(6), 101-106. (In Chinese)http://dx.doi.org/10.3969/j.issn.1673-0461.2006.06.023

Weisbach, M. S. (1988). Outside directors and CEO turnover.Journal of Financial Economics, 20, 431-460. http://dx.doi.org/10.1016/0304-405X(88)90053-0 


\section{Macrothink}

Asian Journal of Finance \& Accounting ISSN 1946-052X 2015, Vol. 7, No. 2

Xia, L. J., \& Fang, Y. Q. (2005). Government control, institutional environment, and firm value: Evidence from the Chinese securities market.Economic Research Journal, 5, 40-51. (In Chinese)

Xia, W. X. (2005). Major shareholders' characteristics and the foundation of audit Committee. Auditing Research, 6, 45-50. (In Chinese)

Xiang, R. (2012). Ultimate ownership structure, ownership characteristics, and the formation of audit committees: Evidence from Chinese listed companies. Journal of Shanxi Finance and Economics University, 34(4), 117-124. (In Chinese)

Xiang, R., Gan, S. D., \& Wang, L. C. (2010). The wealth effect of announcement of audit committee's formation: Empirical evidence from Chinese listed companies. Journal of Sichuan University, $\quad 3, \quad 109-119 . \quad$ (In Chinese) http://dx.doi.org/10.3969/j.issn.1006-0766.2010.03.016

Xu, X. D., \& Chen, X. Y. (2003). Analysis on the largest shareholders' impact on corporate governance and performance. Economic Research Journal, 2, 64-93. (In Chinese)

Zhang, H. H., \& Wang, Z. J. (2010). Government intervention, government object, and state-owned listed companies' over-investment. Nankai Business Review 13(3), 101-108. (In Chinese) http://dx.doi.org/10.3969/j.issn.1008-3448.2010.03.013

Zhang, Y., Zhou, J., \& Zhou, N. (2007). Audit committee quality, auditor independence, and internal control weaknesses. Journal of Accounting and Public Policy, 26, 300-327. http://dx.doi.org/10.1016/j.jaccpubpol.2007.03.001 